\title{
PENGARUH MODEL PEMBELAJARAN INQUIRI DENGAN MASYARAKAT BELAJAR DAN GAYA BELAJAR TERHADAP HASIL BELAJAR MATEMATIKA
}

\author{
Marianto Pardosi \\ Sekolah Dasar Negeri 118299 Aek Raso, Sumatera Utara \\ mardiantopardosi54@gmail.com
}

\begin{abstract}
Abstrak: Penelitian ini bertujuan untuk mengetahui: (1) Perbedaan hasil belajar matematika antara siswa yang diajar dengan model pembelajaran inkuiri dan yang diajar dengan model pembelajaran masyarakat belajar, (2) Perbedaan hasil belajar matematika antara siswa yang memiliki gaya belajar visual dan gaya belajar auditorial, (3) interaksi antara model pembelajaran dan gaya belajar terhadap hasil belajar matematika. Populasi penelitian ini adalah seluruh siswa kelas VI Sekolah Dasar Negeri 118299 Aek Raso, Teknik penarikan dengan cluster random sampling. Metode penelitian menggunakan metode quasi eksperimen dengan desain penelitian faktorial $2 \times 2$. Teknik analisis data menggunakan ANAVA dua jalur pada taraf signifikan $\alpha=0,05$. Temuan penelitian menunjukkan bahwa: (1) hasil belajar matematika siswa yang diajar dengan model pembelajarn inkuiri lebih tinggi daripada hasil belajar siswa yang diajar dengan model pembelajaran masyarakat belajar, (2) hasil belajar matematika siswa yang memiliki gaya belajar visual lebih tinggi daripada hasil belajar siswa yang memiliki gaya belajar auditorial, (3) terdapat interaksi antara model pembelajaran dan gaya belajar terhadap hasil belajar matematika. Perhitungan uji lanjut dengan uji Scheffe menunjukkan perbedaan yang signifikan pada hasil belajar matematika antara model pembelajaran inkuiri dan masyarakat belajar, begitu pula anatara gaya belajar visual dan gaya belajar auditorial.
\end{abstract}

Kata Kunci: model pembelajaran, inquiri, masyarakat belajar, gaya belajar visual, gaya belajar auditorial, matematika

\begin{abstract}
This study aims to find out: (1) Differences in mathematics learning outcomes between students taught with inquiry learning models and those taught with learning communities learning models, (2) Differences in mathematics learning outcomes between students who have visual learning styles and auditory learning styles, (3) the interaction between learning models and learning styles on learning outcomes in mathematics. The population of this research is all students of grade VI of State Elementary School 118299 Aek Raso, withdrawal technique with cluster random sampling. The research method uses a quasiexperimental method with a $2 \times 2$ factorial research design. Data analysis technique uses two-way ANOVA at a significant level $\alpha=0.05$. The research findings show that: (1) the learning outcomes of students who are taught with inquiry learning models are higher than the learning outcomes of students taught with learning models of learning communities, (2) the results of learning mathematics students who have higher visual learning styles than student learning outcomes which has an auditory learning style, (3) there is an interaction between the learning model and learning style on learning outcomes in mathematics. Further test calculations with the Scheffe test show significant differences in mathematics learning outcomes between inquiry learning models and learning communities, as well as between visual learning styles and auditory learning styles.
\end{abstract}

Keywords: learning model, inquiry, learning society, visual learning style, auditory learning style, mathematics

\section{PENDAHULUAN}

Mata pelajaran matematika sebagai salah satu mata pelajaran yang harus dipelajari pada semua kelas VI SD Negeri 118299 Aek Raso bertujuan mengembangkan kemampuan siswa untuk berpikir kritis, sistematis, logis, kreatif, dan bekerjasama secara efektif sehingga mampu bersaing dalam kehidupan modern yang kompetitif saat ini. Kecakapan atau kemahiran matematika yang diharapkan dapat tercapai dalam pembelajaran matematika dituangkan dalam standar kompetensi berupa: (1) menunjukkan pemahaman konsep matematika yang dipelajari, menjelaskan keterkaitan antara konsep, dan mengaplikasikan konsep atau algoritma secara luwes, akurat, efisien, dan tepat, dalam pemecahan masalah, (2) memiliki kemampuan mengkomunikasikan gagasan dengan simbol, tabel, grafik, atau diagram untuk memperjelas keadaan atau masalah, (3) 
menggunakan penalaran pada pola, sifat atau melakukan manipulasi matematika dalam membuat generalisasi, menyusun bukti, atau menjelaskan gagasan dan pernyataan matematika, (4) menunjukkan kemampuan model dalam membuat atau merumuskan, menafsirkan, dan menyelesaikan model matematika dalam pemecahan masalah, dan (5) memiliki sikap menghargai kegunaan matematika dalam kehidupan (Departemen Pendidikan Nasional, 2006). Di samping itu melalui pembelajaran matematika diharapkan siswa mampu bersikap peka, tanggap, dan berperan aktif dalam menggunakan konsep matematika untuk memecahkan masalah di lingkungannya.

Selayaknya siswa kelas VI SD Negeri 118299 Aek Raso diharapkan telah memiliki sejumlah kemampuan dalam mengaplikasikan konsep-konsep matematika dalam kehidupan sehari-hari khususnya dalam hal pemecahan masalah. Namun pada kenyatannya masih banyak siswa yang belum dapat menguasai secara optimal kompetensi-kompetensi dasar dalam pembelajaran matematika, hal ini ditandai dengan masih rendahnya perolehan hasil belajar siswa dalam mata pelajaran matematika (Nurhadi, 2004). Selain itu banyak pula siswa yang beranggapan bahwa matematika berupa mata pelajaran yang sulit dan terkesan menakutkan karena harus menjawab sejumlah persoalan-persoalan yang sulit untuk dikerjakan.

Masih rendahnya hasil belajar matematika dan kurangnya pengetahuan dan kemampuan siswa dalam memahami matematika juga terjadi pada siswa kelas VI SD Negeri 118299 Aek Raso diperoleh nilai ratarata siswa 60,23 diperoleh nilai rata-rata siswa 65,34 dan diperoleh nilai rata-rata 64,50 Nilai rata-rata ini masih di bawah nilai rata-rata ketuntasan minimal.

Untuk mengatasi adanya kesenjangan tersebut, maka salah satu hal yang dapat diterapkan dalam menyampaikan materi mata pelajaran matematika adalah menyesuaikan model pembelajaran yang digunakan dalam proses pembelajaran dengan memperhatikan karakteristik siswa kelas VI SD Negeri 118299 Aek Raso ternyata hingga saat ini perhatian terhadap karakteristik siswa kurang diperhatikan. Padahal dalam menyampaian materi pelajaran harus mempertimbangkan kesesuaiannya dengan karakteristik mata pelajaran dan karakteristik siswa (Nurhadi,
2004). Ada banyak karakteristik siswa yang dapat mempengaruhi proses dan pembelajaran, di antaranya pengetahuan awal, kemampuan berpikir, gaya berpikir, gaya belajar, kreativitas, motivasi belajar, dan lain-lain.

Di kelas VI SD Negeri 118299 Aek Raso perhatian terhadap kesesuain karakteristik siswa, termasuk gaya belajar yang dimiliki siswa dengan pola pembelajaran yang digunakan hingga saat ini belum diperhatikan sepenuhnya. Hal ini tampak dari model pembelajaran yang dilaksanakan, bahwa siswa diperlakukan sama dalam proses pembelajaran. Perhatian guru akan gaya belajar siswa selama ini kurang dikembangkan, materi ajar yang diberikan dalam mata pelajaran matematika secara teoretis memang sudah berisikan hal-hal yang mendukung pengetahuan siswa dalam pemahaman konsep matematika, namun secara praktis, teori-teori ini tidak dikembangkan dan belum diformulasikan secara baik oleh guru dengan mempertimbangkan gaya belajar siswa.

Salah satu upaya yang dapat dilakukan sebagai solusi dalam meningkatkan kemampuan belajar matematika siswa adalah dengan menerapkan model pembelajaran yang tepat dan sesuai dengan karakteristik siswa, agar siswa memperoleh hasil belajar matematika yang memuaskan sesuai dengan yang diharapkan. Ada banyak model pembelajaran yang dapat digunakan, khususnya pada model pembelajaran kontekstual (Joice and Weil, 2009), seperti model inkuiri, pemerosesan informasi, peningkatan kapasitas berpikir, pembelajaran non directive, pembelajaran berbasis masalah (problem based instruction), pembelajaran aktif, pembelajaran efektif, pembelajaran kooperatif, pembelajaran berbasis masyarakat belajar, pemodelan, dan sebagainya.

\section{Hakikat Belajar Matematika dan Hasil Belajar Matematika}

Menurut Bruner (dalam Sudjana, 2001) belajar yang terbaik haruslah merupakan proses berpikir, dan berpikir pada hakikatnya merupakan proses kognitif, sehingga manusia membedakan, memilih, dan menentukan objek, serta kemampuan untuk mengkonstruksi kembali informasi yang telah diterima. Sedangkan hakikat belajar menurut Dahar (1989) adalah adanya perubahan tingkah laku. Perubahan tingkah laku sebagai hasil belajar ditunjukkan dengan berbagai aspek seperti perubahan pengetahuan, pemahaman, persepsi, 
motivasi, dan gabungan dari aspek-aspek tersebut. Sependapat dengan hal ini Tirtarahardja dan Sula (2000) mengemukakan bahwa belajar adalah sebagai aktivitas pengembangan diri melalui pengalaman, bertumpu pada kemampuan pada diri siswa di bawah bimbingan guru. Belajar merupakan perubahan seluruh tingkah laku individu secara bertahap yang relatif menetap sebagai hasil pengalaman dan interaksi dengan lingkungan yang melibatkan proses kognitif.

Lebih jauh lagi, Fudyartanta (2002) merangkum berbagai pendapat para ahli psikologi tentang pengertian belajar antara lain: (a) belajar adalah perubahan tingkah laku melalui pengalaman dan latihan, (b) belajar adalah suatu proses aktif yang perlu dirangsang dan dibimbing ke arah hasil-hasil yang diinginkan, (c) belajar adalah perubahan yang dialami secara relatif abadi dalam tingkah laku yang merupakan suatu fungsi dari tingkah laku sebelumnya, (d) belajar adalah membawa perubahan-perubahan dalam tingkah laku dari organisme dan (e) belajar sebagai perubahan relatif yang permanen dalam potensialitas. Dari pengertian belajar tersebut dapat dinyatakan bahwa pada hakikatnya belajar adalah proses perubahan tingkah laku atau kecakapan manusia. Perubahan tingkah laku ini bukan disebabkan oleh proses pertumbuhan yang bersifat fisiologis atau proses kematangan. Perubahan yang terjadi karena proses belajar yang dialami oleh peserta didik. Maka hasil belajar siswa baik berupa perubahan pengetahuan, keterampilan, dan sikap, sangat tergantung pada bagaimana individu berinteraksi dengan lingkungannya termasuk guru.

Belajar matematika memiliki fungsi tersendiri yang pada dasarnya terjadi melalui proses yang diarahkan pada suatu tujuan tertentu. Hudojo (1988) menyatakan matematika pada hakikatnya berkenaan dengan ide-ide abstrak, susunan materi yang terurut dan saling terkait, tidak terjadi pertentangan antar konsep yang satu dengan yang lain, ilmu matematika tersusun secara struktur, penalaran yang digunakan adalah penalaran deduktif.

Fungsi matematika menurut Nurhadi (2004) adalah mengembangkan kemampuan menghitung, mengukur, menurunkan dan menggunakan rumus matematika yang diperlukan dalam kehidupan sehari-hari melalui materi pengukuran dan geometri, aljabar dan trigonometri, matematika juga berfungsi mengembangkan

kemampuan mengkomunikasikan gagasan dengan bahasa melalui model matematika yang dapat berupa kalimat dan persamaan matematika, diagram, grafik, atau tabel. Topik-topik pembahasan di dalam mata pelajaran matematika tersusun secara hirarkis dan ketat, mulai dari yang mendasar atau yang termudah sampai kepada yang paling sukar, oleh karenanya menurut Hudojo (1983) mempelajari matematika haruslah bertahap serta mendasar kepada pengalaman belajar yang lalu.

\section{Hakikat Model Pembelajaran Inkuiri}

Inkuiri yang dalam bahasa Inggris inkuiri, berarti mempertanyakan, pemeriksaan atau penyelidikan. Dengan melakukan penyelidikan, siswa akhirnya dapat memperoleh suatu penemuan. Model ini berkembang dari ide John Dewey yang terkenal dengan "'problem solving method" atau metode pemecahan masalah. Bruner dalam Hasibuan dan Moejiono (1993) yang mengemukakan bahwa pencarian (inkuiri) mengandung makna sebagai berikut: (1) dapat membangkitkan potensi intelektual siswa karena seseorang hanya dapat belajar dan mengembangkan pikirannya jika ia menggunakan potensi inlelektualnya untuk berpikir; (2) siswa yang semula memperoleh extrinsic reward dalam keberhasilan belajar (mendapat nilai yang baik), dalam pendekatan inkuiri akan dapat memperoleh intrinsic reward (kepuasan diri), (3) siswa dapat mempelajari heuristik (mengolah pesan atau informasi) dari penemuan, artinya bahwa cara untuk mempelajari teknik penemuan ialah dengan jalan memberikan kesempatan kepada siswa untuk mengadakan penelitian sendiri, dan (4) dapat menyebabkan ingatan bertahan lama sampai internalisasi pada diri siswa.

Menurut Schuman (dalam Wardani, 2000) anak memiliki motivasi alamiah untuk meneliti atau berinkuiri. Oleh karena itu inkuiri membutuhkan partisipasi aktif dari siswa untuk meneliti sendiri secara ilmiah masalah yang dihadapi. Ini tidaklah berarti bahwa dengan inkuiri siswa akan dididik menjadi seorang ilmuan, karena inkuiri mencoba membawa siswa ke dalam situasi yang memberikan kesempatan untuk menggunakan apa yang telah diketahui dan menyadari apa yang mereka lakukan itu adalah hasil perolehan mereka sendiri dan bukan perolehan gurunya. Oleh karena itu, sasaran utama model ini adalah keterlibatan siswa secara maksimal dalam 
proses pembelajaran.

Amien (1987) menyatakan bahwa inkuiri learning memberikan waktu bagi siswa untuk mengasimilasi dan mongakomodasi informasi, mendorong siswa untuk berpikir inisiatif dan merumuskan hipotesisnya sendiri. Proses belajar meliputi semua aspek yang menunjang siswa menuju ke pembentukan manusia seutuhnya, misalnya; di dalam situasi proses inkuiri, siswa tidak hanya belajar tentang konsep-konsep dan prinsip-prinsip. tetapi ia juga mengalami proses belajar tentang tentang pengarahan diri sendiri, tanggungjawab, komunikasi sosial dan sebagainya.

Menurut Joyce dan Weil (2009) model pembelajaran inkuiri merupakan salah satu model yang termasuk dalam kelompok model pengajaran memproses informasi (the information-processing family). Model pengajaran memproses informasi menekankan cara-cara dalam meningkatkan dorongan alamiah manusia untuk membentuk makna tentang dunia dengan memeperoleh dan mengolah data, merasakan masalah-masalah dan menghasilkan solusi-solusi yang tepat, serta mengembangkan konsep dan bahasa untuk menstransfer solusi atau data tersebut.

\section{Hakikat Model Pembelajaran Masyarakat belajar}

Masyarakat Belajar atau Learning Community merupakan bagian dari model pembelajaran kontekstual yang mengarahkan siswa pada sejumlah kegiatan yang mengasumsikan bahwa secara natural pikiran mencari makna konteks sesuai dengan situasi nyata lingkungan seseorang. Kontekstual merupakan sebuah pendekatan pembelajaran yang mengakui dan menunjukkan kondisi alamiah dari pengetahuan. Joyce dan Weil (2009) mengelompokkan masyarakat belajar dalam kelompok model pengajaran sosial. Model-model sosial dibangun untuk mendapatkan keuntungan dari fenomena dengan cara membuat komunitas pembelajaran. Inti dari model pembelajaran ini adalah bekerjasama dalam mempelajari hal-hal yang sifatnya akademis dan berupaya untuk mempersiapkan peserta didik untuk menjadi warga Negara yang baik serta membentuk kehidupan social yang memuaskan.

Menurut Trianto (2007), masyarakat belajar mengarahkan siswa untuk saling berbagi dengan teman dalam satu kelompok. Fungsi guru hanyalah sebagai fasilitator. Masyarakat belajar dapat terjadi apabila terdapat proses komunikasi dua arah. Dalam masyarakat belajar dua kelompok atau lebih yang terlibat dalam komunikasi pembelajaran saling belajar satu sama lain. Menurut Nurhadi (2004) masyarakat belajar sebagai bagian pembelajaran kontekstual memenuhi beberapa syarat sebagai berikut: (1) sekelompok orang yang terikat dalam kegiatan belajar, (2) Bekerjasama dengan orang lain lebih baik daripada belajar sendiri, (3) saling tukar pengalaman (4) berbagi ide, (5) berbicara dan berbagi pengalaman dengan orang lain. (6) ada kerjasama untuk memecahkan masalah, (7) hasil pembelajaran secara kelompok akan lebih baik daripada belajar sendiri (9) ada fasilitator/guru yang memandu proses belajar dalam kelompok.

Menurut McMillan dan Chavis (1986) ada empat faktor utama yang didefinisikan rasa kebersamaan dalam masyarakat belajar, yaitu: (1) kenggotaan, (2) pengaruh, (3) pemenuhan kebutuhan individu, dan (4) mengalami kegiatan dan hubungan emosional. Jadi, para siswa belajar masyarakat harus merasakan rasa kesetiaan dan seterusnya keanggotaan yang mendorong keinginan mereka untuk tetap berkerja dan membantu orang lain, juga hal-hal yang dilakukan dalam anggota kelompok harus mempengaruhi apa yang terjadi di kelompok tersebut. Selain itu dalam masyarakat belajar harus diberikan kesempatan kepada para peserta untuk memenuhi kebutuhan-kebutuhan khusus (pemenuhan) dengan mengungkapkan pendapat pribadi, meminta bantuan atau infoemasi spesifik dan berbagi cerita keladian dengan isu tertentu disertakan (hubungan emosional) dan pengelaman emosional.

Menurut Trianto (2007) dalam masyarakat belajar hasil belajar yang diperoleh merupakan hasil sharing dengan teman. Dengan saling berbagi informasi, siswa akan memiliki suatu keterikatan social dengan teman dalam satu kelompoknya. Lingkungan belajar untuk pembelajaran masyarakat belajar dicirikan oleh proses demokrasi dan peran aktif siswa dalam menentukan bagaimana mempelajari sesuatu (Departemen pendidikan nasional, 2005). Tingkah laku siswa juga tidak boleh dikelola secara ketat dalam kelompoknya, model ini sangat berguna membantu siswa memahami konsep-konsep sulit, membantu siswa menumbuhkan kemampuan kerjasama, berpikir kritis, dan kemampuan membantu teman. 


\section{Hakikat Gaya Belajar}

DePorter \& Hernacki (1992) mengatakan bahwa gaya belajar adalah kunci untuk mengembangkan kinerja dalam pekerjaan, di sekolah, dan dalam situasi-situasi antar pribadi. Pada awal pengalaman belajar, salah satu diantara langkah-langkah pertama kita adalah mengenali modalitas seseorang sebagai modalitas visual, auditorial, atau kinestetik (VA-K). Madden (2002) mengemukakan bahwa "Setiap orang unik. Sebagian orang belajar terutama dengan menggunakan keterampilan auditori untuk memproses informasi yang didengar. Sebagian lagi lebih menggunakan keterampilan visual untuk memproses informasi yang sama." Pembelajar visual suka melihat gambar atau informasi dalam bentuk tulisan. Tetapi sebagian lagi suka menggunakan keterampilan fisik atau pengalaman. Seorang pembelajar fisik, yang juga disebut pembelajar kinestetis, suka menyentuh peralatan dan belajar dengan baik melalui peranan peragaan.

Menurut Gunawan (2004), bahwa gaya belajar adalah cara yang lebih kita sukai dalam melakukan kegiatan berpikir, memproses dan mengerti suatu informasi. Ada teknik-teknik yang secara alami digunakan untuk memperoleh informasi. Saluran masuk paling alami merupakan gaya belajar yang lebih disukai. Tetapi kita juga bisa belajar menggunakan teknik-teknik yang sama sekali berbeda dari saluran masuk utama itu.

Lebih lanjut Amir (2004) menjelaskan bahwa manusia visual menerima dan memproses informasi dengan cara melihat dan menciptakan gambaran mentalnya. Manusia auditori menerima dan memproses informasi dengan mendengarkan kata-kata dan suarasuara. Sedangkan manusia kinestetik menerima dan memproses informasi melalui perasaan dan sensasi. Dryden dan Vos (2002) mengemukakan bahwa untuk menemukan gaya belajar yang disukai siswa jalan yang terbaik adalah bertanya.

Ada beberapa ciri masing-masing gaya belajar yang dikemukakan oleh dePorter dan hernacki (1992) ciri-ciri tersebut antara lain: (1) Orang -orang Visual mempunyai ciri-ciri, rapi dan teratur; berbicara dengan cepat; perencana dan pengatur jangka panjang yang baik; teliti terhadap detail; mementingkan penampilan, baik dalam hal pakaian maupun presentasi;pengeja yang baik dan dapat melihat kata-kata yang sebenarnya dalam pikiran mereka; mengingat apa yang dilihat, daripada yang didengar; mengingat dengan assosiasi visual; biasanya tidak terganggu oleh keributan; mempunyai masalah untuk mengingat instruksi verbal kecuali jika ditulis, dan seringkali minta bantuan orang untuk mengulanginya; pembaca cepat dan tekun; lebih suka membaca daripada dibacakan; membutuhkan pandangan dan tujuan yang menyeluruh dan bersikap waspada sebelum mental merasa pasti tentang suatu masalah atau proyek; mencoret-coret tanpa arti selama berbicara di telepon dan dalam rapat;lupa menyampaikan pesan verbal kepada orang lain; sering menjawab pertanyaan dengan jawaban singkat ya atau tidak; lebih suka melakukan demonstrasi daripada berpidato; lebih suka seni daripada musik. (2) Orangorang Auditorial mempunyai ciri-ciri : berbicara kepada diri sendiri saat bekerja; mudah terganggu oleh keributan; menggerakkan bibir mereka dan mengucapkan tulisan di buku ketika membaca; senang membaca dengan keras dan mendengarkan; dapat mengulangi kembali dan menirukan nada, birama, dan warna suara; merasa kesulitan untuk menulis, tetapi hebat dalam bercerita; berbicara dalam irama yang terpola; biasanya berbicara fasih; lebih suka musik daripada seni; belajar dengan mendengarkan dan mengingat apa yang didiskusikan daripada yang dilihat; suka berbicara, suka berdiskusi dan menjelaskan sesutu dengan panjang lebar; mempunyai masalah dengan pekerjaanpekerjaan yang melibatkan visualisasi; seperti memotong bagian-bagian hingga sesuai satu sama lain; lebih pandai mengeja dengan keras daripada menuliskannya; lebih suka gurauan lisan dari pada membaca komik. (3) Orangorang Kinestetik mempunyai ciri-ciri : berbicara dengan perlahan; menanggapi perhatian fisik; meyentuh orang untuk mendapat perhatian mereka; berdiri dekat ketika berbicara dengan orang; selalu berorientasi pada fisik dan banyak bergerak; mempunyai perkembangan awal otot-otot yang besar; belajar melalui manipulasi dan praktek; menghafal dengan cara berjalan dan melihat; menggunakan jari sebagai penunjuk ketika membaca; banyak menggunakan isyarat tubuh; tidak dapat duduk diam untuk waktu lama

Gunawan (2004) mengemukakan bahwa pada umumnya, orang jarang menggunakan hanya satu gaya belajar. Jarang ada orang yang hanya belajar secara visual, atau hanya secara auditori, atau hanya secara kinestetik. Biasanya akan ada kombinasi antara visual dan auditori, 
atau auditori dan kinestetik, atau bahkan kombinasi antara ketiga gaya belajar ini. Dari hasil penelitian diketahui bahwa jumlah orang yang belajar secara visual $27 \%$, auditori $34 \%$, dan kinestetik 39\% (Gunawan, 2004) Hal ini menjawab pertanyaan mengapa banyak sekali siswa yang mengalami kesulitan belajar.Mengenali modalitas belajar orang lain adalah kunci penting untuk menghasilkan presentasi yang lebih efektif. Misalnya, bila kita tahu bahwa atasan anda adalah orang visual, akan lebih memungkinkan bagi kita untuk menyampaikan maksud jika kita menggunakan material visual, seperti slide dan makalah, dalam suatu presentasi.

Rumusan masalah dalam penelitan ini adalah: (1) Apakah hasil belajar matematika siswa kelas VI SD Negeri 118299 Aek Raso yang diajar dengan model pembelajaran inkuiri lebih tinggi daripada hasil belajar siswa yang diajar dengan model pembelajaran masyarakat belajar; (2) Apakah hasil belajar matematika siswa kelas VI SD Negeri 118299 Aek Raso yang memiliki gaya belajar visual lebih tinggi daripada siswa yang memiliki gaya belajar auditorial; dan (3) Apakah terdapat interaksi antara model pembelajaran dengan gaya belajar terhadap hasil belajar matematika siswa kelas VI SD Negeri 118299 Aek Raso

\section{METODE}

Penelitian dilaksanakan di SD Negeri 118299 Aek Raso. Penelitian ini dilaksanakan pada semester genap kelas VI. Desain penelitian yang digunakan adalah desain faktorial $2 \times 2$, seperti terlihat pada Tabel 2 . yang mengelompokkan model pembelajaran inkuiri dengan model pembelajaran masyarakat belajar terhadap gaya belajar visual dan gaya belajar auditorial.

Tabel 1. Desain Faktorial $2 \times 2$

\begin{tabular}{|l|l|l|}
\hline \multirow{2}{*}{ Gaya belajar $(\mathrm{B})$} & \multicolumn{2}{|c|}{ Model Pembelajaran $(\mathrm{A})$} \\
\cline { 2 - 3 } & Inkuiri $\left(\mathrm{A}_{1}\right)$ & $\begin{array}{l}\text { Masyarakat } \\
\text { belajar( } \mathrm{A}_{2}\end{array}$ \\
\hline Visual $\left(\mathrm{B}_{1}\right)$ & $\mathrm{A}_{1} \mathrm{~B}_{1}$ & $\mathrm{~A}_{2} \mathrm{~B}_{1}$ \\
\hline Auditorial $\left(\mathrm{B}_{2}\right)$ & $\mathrm{A}_{1} \mathrm{~B}_{2}$ & $\mathrm{~A}_{2} \mathrm{~B}_{2}$ \\
\hline
\end{tabular}

Keterangan :

$$
\begin{aligned}
& \mathrm{A}=\text { Model pembelajaran } \\
& \mathrm{B}=\text { Gaya belajar } \\
& \mathrm{A}_{1}=\text { Model pembelajaran inkuiri }
\end{aligned}
$$

$$
\begin{aligned}
& \mathrm{A}_{2}= \text { Model pembelajaran masyarakat } \\
& \text { belajar } \text { Gaya belajar visual } \\
& \mathrm{B}_{1}= \text { Gaya belajar auditorial } \\
& \mathrm{B}_{2}= \text { Hasil belajar matematika siswa yang } \\
& \text { diajar dengan menggunakan model } \\
& \mathrm{A}_{1} \mathrm{~B}_{1}= \begin{array}{l}
\text { pembelajaran inkuiri pada siswa } \\
\text { dengan gaya belajar visual }
\end{array} \\
& \mathrm{A}_{1} \mathrm{~B}_{2}= \text { Hasil belajar matematika siswa yang } \\
& \begin{array}{l}
\text { diajar dengan menggunakan model } \\
\text { pembelajaran inkuiri pada siswa } \\
\text { dengan gaya belajar auditorial. }
\end{array} \\
& \mathrm{A}_{2} \mathrm{~B}_{1}= \text { Hasil belajar matematika siswa yang } \\
& \begin{array}{l}
\text { diajar dengan menggunakan model } \\
\text { pembelajaran masyarakat belajar pada } \\
\text { siswa dengan gaya belajar tinggi. }
\end{array} \\
& \mathrm{A}_{2} \mathrm{~B}_{2}= \begin{array}{l}
\text { Hasil belajar matematika siswa yang } \\
\text { diajar dengan menggunakan model } \\
\text { pembelajaran masyarakat belajar pada }
\end{array} \\
& \text { siswa dengan gaya belajar auditorial. }
\end{aligned}
$$

\section{Teknik Analisis Data}

Teknik analisis data dalam penelitian ini menggunakan analisis deskriptif dan analisis inferensial. Teknik analisis deskriptif dimaksudkan untuk mendeskripsikan data penelitian meliputi mean, median, standard deviasi dan kecenderungan data. Data yang telah diperoleh selanjutnya disajikan dalam bentuk tabel distribusi frekuensi dan histogram. Teknik analisis inferensial digunakan untuk menguji hipotesis penelitian dengan menggunakan teknik analisis varians (ANAVA) dua jalur. Jika hasil penelitian menunjukkan terdapat interaksi antara model pembelajarn dengan gaya belajar, maka dilakukan uji lanjut. Uji lanjut yang digunakan pada penelitian ini adalah uji Scheffe jika $n$ tiap-tiap sel berbeda, dan uji Tuckey jika n tiap-tiap sel sama. Untuk menggunakan ANAVA dua jalur perlu dipenuhi beberapa syarat yaitu: (1) data yang digunakan harus berdistribusi normal, untuk menguji normalitas data digunakan uji Liliefors, dan (2) data harus memiliki varians populasi homogen, untuk menguji homogenitas varians digunakan uji F (Fisher) dan uji Bartlet. Semua pengujian dilakukan pada taraf $\alpha=$ 0,05 .

Rumusan hipotesis statistik dalam penelitian ini adalah sebagai berikut:

a. Hipotesis pertama :

Ho $: \mu_{A 1} \leq \mu_{A 2}$ 
$\mathrm{H} 1: \mu_{A 1}>\mu_{A 2}$

b. Hipotesis kedua :

Ho : $\mu_{B 1} \leq \mu_{B 2}$

H1 $: \mu_{B 1}>\mu_{B 2}$

c. Hipotesis ketiga :

Ho : $\mathrm{A} \times \mathrm{B}=0$

$\mathrm{H} 1: \mathrm{A} \times \mathrm{B} \neq 0$

Keterangan :

A $\quad=$ Model Pembelajaran

$\mathrm{B}=$ Gaya belajar

$\mathrm{A}_{1} \quad=$ Model pembelajaran inkuiri

$\mathrm{A}_{2}=$ Model pembelajaran masyarakat belajar

$\mathrm{B}_{1} \quad=$ Gaya belajar visual

$\mathrm{B}_{2} \quad=$ Gaya belajar auditorial

$\mu_{A 1}=$ Rata-rata hasil belajar matematika siswa yang memperoleh pembelajaran dengan model pembelajaran inkuiri

$\mu_{A 2}=$ Rata-rata hasil bealajar matematika siswa yang memperoleh pembelajaran dengan model pembelajaran masyarakat belajar

$\mu_{B 1} \quad=$ Rata-rata hasil belajar matematika siswa yang memiliki gaya belajar visual
$\mu_{B 1} \quad=$ Rata-rata hasil belajar matematika siswa yang memiliki gaya belajar auditorial.

$\mathrm{A} \times \mathrm{B}=$ Interaksi antara model pembelajaran dengan gaya belajar.

\section{HASIL DAN PEMBAHASAN \\ Hasil}

Pengujian hipotesis dilakukan untuk membuktikan kebenaran hipotesis yang telah ditetapkan sehingga diperoleh data apakah hipotesis yang dirancnag dalam sebuah penelitian ditolak atau diterima. Untuk keperluan pengujian hipotesis dengan menggunakan teknik analisis varian dua jalur (ANAVA) faktorial $2 \times 2$ dan kemudian dilanjutkan dengan uji lanjut dengan menggunakan uji Scheffe, maka diperlukan harga rata-rata tiap kelompok perlukan sebagai sumber data penelitian, berikut ini disajikan rangkuman data hasil belajar matematika siswa kelas VI SD Negeri 118299 Aek Raso sebagai sumber pengolahan data untuk pengujian hipotesis. Rangkuman data tersebut dapat dilihat pada Tabel 2 dengan menggunakan analisis deskriptif

Tabel 2. Rangkuman Data Hasil Perhitungan Analisis Deskriptif.

\begin{tabular}{|c|c|c|c|c|}
\hline \multirow{2}{*}{\multicolumn{2}{|c|}{$\begin{array}{c}\text { RINGKASAN } \\
\text { DATA }\end{array}$}} & \multicolumn{2}{|c|}{ MODEL PEMBELAJARAN } & \multirow{2}{*}{ Total } \\
\hline & & Inkuiri & Masyarakat Belajar & \\
\hline \multirow{2}{*}{$\begin{array}{l}\text { Gaya } \\
\text { Belajar }\end{array}$} & Visual & $\begin{array}{c}\mathrm{n}_{1}=21 \\
\sum \mathrm{P}_{1}=576 \\
\sum \mathrm{X}^{2}{ }_{1}=15178 \\
\overline{\mathrm{X}}_{1}=26,23 \\
\mathrm{~s}^{2}{ }_{1}=5,79\end{array}$ & $\begin{array}{c}\mathrm{n}_{3}=19 \\
\sum \mathrm{P}_{3}=473 \\
\sum \mathrm{X}_{3}^{2}=10775 \\
\overline{\mathrm{X}}_{3}=22,70 \\
\mathrm{~S}^{2}{ }_{3}=5,78\end{array}$ & $\begin{aligned} \mathrm{N}_{1,3} & =40 \\
\sum \mathrm{P}_{1,3} & =1049 \\
\sum \mathrm{X}_{1,3}^{2} & =25953 \\
\overline{\mathrm{X}}_{1,3} & =24,41 \\
\mathrm{~s}_{1,3}^{2} & =9,14\end{aligned}$ \\
\hline & Auditorial & $\begin{array}{c}\mathrm{n}_{2}=22 \\
\sum \mathrm{P}_{2}=338 \\
\sum \mathrm{X}_{2}=7230 \\
\overline{\mathrm{X}}_{2}=21,00 \\
\mathrm{~s}_{2}=4,92\end{array}$ & $\begin{aligned} \mathrm{n}_{4} & =18 \\
\sum \mathrm{P}_{4} & =351 \\
\sum \mathrm{X}_{4}{ }_{4} & =8295 \\
\overline{\mathrm{X}}_{4} & =23,37 \\
\mathrm{~S}_{4}{ }_{4} & =5,41\end{aligned}$ & $\begin{array}{c}\mathrm{N}_{2,4}=40 \\
\sum \mathrm{P}_{2,4}=689 \\
\sum \mathrm{X}_{2,4}^{2}=15525 \\
\overline{\mathrm{X}}_{2,4}=22,00 \\
\mathrm{~s}_{2,4}^{2}=5,79\end{array}$ \\
\hline \multicolumn{2}{|c|}{ Total } & $\begin{array}{c}\mathrm{N}_{1,2}=43 \\
\sum \mathrm{P}_{1,2}=914 \\
\sum \mathrm{X}_{1,2}^{2}=22408 \\
\overline{\mathrm{X}}_{1,2}=23,97 \\
\mathrm{~s}^{2}{ }_{1,2}=11,58\end{array}$ & $\begin{array}{c}\mathrm{N}_{3,4}=37 \\
\sum \mathrm{P}_{3,4}=824 \\
\sum \mathrm{X}_{3,4}^{2}=19070 \\
\overline{\mathrm{X}}_{3,4}=22,88 \\
\mathrm{~s}_{3,4}^{2}=7,95\end{array}$ & $\begin{aligned} \mathrm{N}_{\mathrm{g}} & =80 \\
\sum \mathrm{P}_{\mathrm{g}} & =1738 \\
\sum \mathrm{X}_{\mathrm{g}}^{2} & =41478 \\
\overline{\mathrm{X}}_{\mathrm{g}} & =23,46 \\
\mathrm{~S}_{\mathrm{g}}^{2} & =9,20\end{aligned}$ \\
\hline
\end{tabular}

Setelah data tabel 2 diolah dengan ANAVA 2 jalur faktorial $2 \times 2$, maka diperoleh hasil analisis seperti ditunjukkan pada Tabel 3. 
Tabel 3. Ringkasan Perhitungan ANAVA Faktorial 2x2

\begin{tabular}{|l|c|c|c|c|c|c|}
\hline \multicolumn{1}{|c|}{ Sumber Varians } & $\mathbf{J K}$ & $\mathbf{d k}$ & $\mathbf{K T}$ & $\mathbf{F}_{\text {hitung }}$ & $\begin{array}{c}\mathbf{F}_{\text {tabel }} \\
(\mathbf{a}=\mathbf{0 , 0 5})\end{array}$ & Ket. \\
\hline Model & 25,04 & 1 & 25,04 & 4,5 & & Signifikan \\
Gaya Berpikir & 84,79 & 1 & 84,79 & 15,22 & 3,97 & Signifikan \\
Interaksi & 158,77 & 1 & 158,77 & 28,5 & & Signifikan \\
\hline Dalam kelompok (galat) & 268,6 & 76 & 5,69 & & & \\
Total & 839,9 & 79 & & & & \\
\hline
\end{tabular}

Pada tabel ringkasan ANAVA untuk model pembelajaran diperoleh $\mathrm{F}_{\text {hitung }}=4,50>$ $\mathrm{F}_{\text {tabel }}=3,97$, untuk gaya belajar $\mathrm{F}_{\text {hitung }}=15,22>$ $\mathrm{F}_{\text {tabel }}=3,97$, dan untuk interaksi diperoleh $\mathrm{F}_{\text {hitung }}$ $=28,50>\mathrm{F}_{\text {tabel }}=3,97$, berdasarkan data-data tersebut, dapat disimpulkan adanya interaksi antara model pembelajaran dengan gaya belajar yang mempengaruhi hasil belajar matematika siswa.

Hasil Belajar Matematika Antara Siswa yang Diajar dengan Model Imkuiri dan Model Pembelajaran Masyarakat Belajar Pengujian dilakukan terhadap hipotesis statistik yang dirumuskan sebagai berikut:

$$
\begin{aligned}
& H o: \mu_{A 1} \leq \mu_{A 2} \\
& H a: \mu_{A 1}>\mu_{A 2}
\end{aligned}
$$

Pernyataan hipotesis tersebut adalah :

$\mathrm{Ho}=$ Hasil belajar matematika siswa yang diajar dengan model inkuiri lebih kecil atau sama dengan hasil belajar siswa yang diajar dengan model pembelajaran masyarakat belajar

$\mathrm{Ha}=$ Rata-rata hasil belajar matematika siswa yang diajar dengan model pembelajarn inkuiri lebih tinggi daripada siswa yang diajar dengan model pembelajaran masyarakat belajar.

Dari hasil perhitungan analisis tentang perbedaan hasil belajar matematika siswa yang diajar dengan model inkuiri sebesar $\overline{\mathrm{X}}=23,97$ dan model pembelajaran masyarakat belajar $\bar{X}=22,88$, didapat hasil perhitungan $F_{h}$ sebesar 4,50 dan harga tabel $F_{t}$ adalah 3,97. Dengan demikian temuan penelitian menyimpulkan, bahwa hipotesis penelitian yang menyatakan: rata-rata hasil belajar matematika siswa yang diajar dengan model inkuiri lebih tinggi daripada hasil belajar matematika siswa yang diajar dengan model pembelajaran masyarakat belajar pada taraf kepercayaan $\alpha=0,05$ telah teruji kebenarannya.

Perbedaan Hasil Belajar Matematika Antara Siswa dengan Gaya Belajar Visual dan

Gaya Belajar Auditorial.

Pengujian dilakukan terhadap hipotesis statistik yang dirumuskan sebagai berikut:

$$
\begin{aligned}
H o: \mu_{B 1} \leq \mu_{B 2} & \\
H a & : \mu_{B 1}>\mu_{B 2}
\end{aligned}
$$

Pernyataan hipotesis tersebut adalah :

$\mathrm{H}_{0}=$ Hasil belajar matematika siswa yang memiliki gaya belajar visual lebih kecil atau sama dengan hasil belajar siswa yang memiliki gaya belajar auditorial

$\mathrm{Ha}=$ Rata-rata hasil belajar matematika siswa yang memiliki gaya belajar visual lebih tinggi daripada hasil belajar matematika siswa yang memiliki gaya belajar auditorial

Hasil perhitungan analisis varian tentang perbedaan hasil belajar matematika antara siswa yang memiliki gaya belajar visual dan gaya belajar auditorial dengan rata-rata $\bar{X}$ $=24,41$ dan $\bar{X}=22,00$. Berdasarkan Tabel 4.16 dapat dihitung $\mathrm{F}_{\mathrm{h}}=15,22$ dan harga tabel untuk $\alpha=0,05$ dengan $\mathrm{dk}(1)$ diperoleh $\mathrm{F}_{\mathrm{t}}=$ 3,97 sehingga dapat dinyatakan $F_{h}(15,22)>F_{t}$ $(3,97)$. Dengan demikian temuan penelitian menyimpulkan hipotesis penelitian yang menyatakan: hasil belajar matematika siswa yang memiliki gaya belajar visual lebih tinggi daripada hasil belajar siswa yang memiliki gaya belajar auditorial pada taraf kepercayaan $\alpha=$ 0,05 telah teruji kebenarannya.

Interaksi Antara Model Pembelajaran dan Gaya Belajar Terhadap Hasil Belajar Matematika Siswa

Pengujian dilakukan terhadap hipotesis statistik yang dirumuskan sebagai berikut : 
Ho : Interaksi $(\mathrm{B} \times \mathrm{T})=0 \quad$;

Ha : Interaksi $(B \times T) \neq 0$

Pernyataan hipotesis tersebut adalah :

Ho = Tidak terdapat interaksi antara model pembelajaran dan gaya belajar terhadap hasil belajar matematika siswa.

$\mathrm{Ha}=$ Terdapat interaksi antara model pembelajaran dan gaya belajar terhadap hasil belajar matematika siswa.

Berdasarkan hasil perhitungan ANAVA faktorial $2 \times 2$ diperoleh hasil perhitungan $\mathrm{F}_{\mathrm{h}}=$ 28,50 dengan harga tabel $F_{t}$ untuk taraf kepercayaan $(\alpha)$ sebesar 0,05 dengan $\mathrm{dk}=1$ adalah $F_{t}=3,97$ sehingga dapat dinyatakan $F_{h}$ $(28,50)>F_{t}(3,97)$, dengan demikian dapat disimpulkan pernyataan hipotesis penelitian yang menyatakan: terdapat interaksi antara model pembelajaran dan gaya belajar terhadap hasil belajar matematika siswa telah teruji kebenarannya pada taraf signifikan $\alpha=0,05$.

Data yang diperoleh dalam penelitian ini berasal dari sampel yang jumlahnya berbeda untuk setiap sel Anava. Sehingga perlu dilakukan uji Schefee, hasil pengujian dengan menggunakan uji Scheffee dapat dilihat dalam Tabel 4.

Tabel 4. Ringkasan Hasil Pengujian Dengan Menggunakan Uji Scheffe

\begin{tabular}{|c|c|c|c|c|c|}
\hline \multirow{2}{*}{ No } & \multicolumn{2}{|c|}{ Hipotesis Statistik } & \multirow{2}{*}{$F_{\text {hitung }}$} & \multicolumn{2}{|c|}{$\mathrm{F}_{\text {tabel }}$} \\
\cline { 5 - 6 } & & & $\alpha=5 \%$ & $\alpha=1 \%$ \\
\hline 2 & $\mathrm{Ho}: \mu_{1}=\mu_{3}$ & $\mathrm{Ha}: \mu_{1}>\mu_{3}$ & 38,41 & 2,70 & 4,30 \\
\hline 3 & $\mathrm{Ho}: \mu_{1}=\mu_{2}$ & $\mathrm{Ha}: \mu_{1}>\mu_{2}$ & 27,54 & 2,70 & 4,30 \\
\hline 4 & $\mathrm{Ho}: \mu_{1}=\mu_{4}$ & $\mathrm{Ha}: \mu_{1}>\mu_{4}$ & 7,93 & 2,70 & 4,30 \\
\hline 5 & $\mathrm{Ho}: \mu_{2}=\mu_{4}=\mu_{4}$ & $\mathrm{Ha}: \mu_{2}>\mu_{4}$ & 4,73 & 2,70 & 4,30 \\
\hline 6 & $\mathrm{Ha}: \mu_{3}>\mu_{4}$ & 4,10 & 2,70 & 4,30 \\
\hline
\end{tabular}

Hasil pengujian hipotesis di atas, menunjukkan adanya interaksi antara model pembelajaran dan gaya belajar terhadap hasil belajar matematika. Interaksi antara model pembelajaran dengan gaya belajar tersebut dapat divisualisasikan dalam bentuk grafis pada gambar 1.

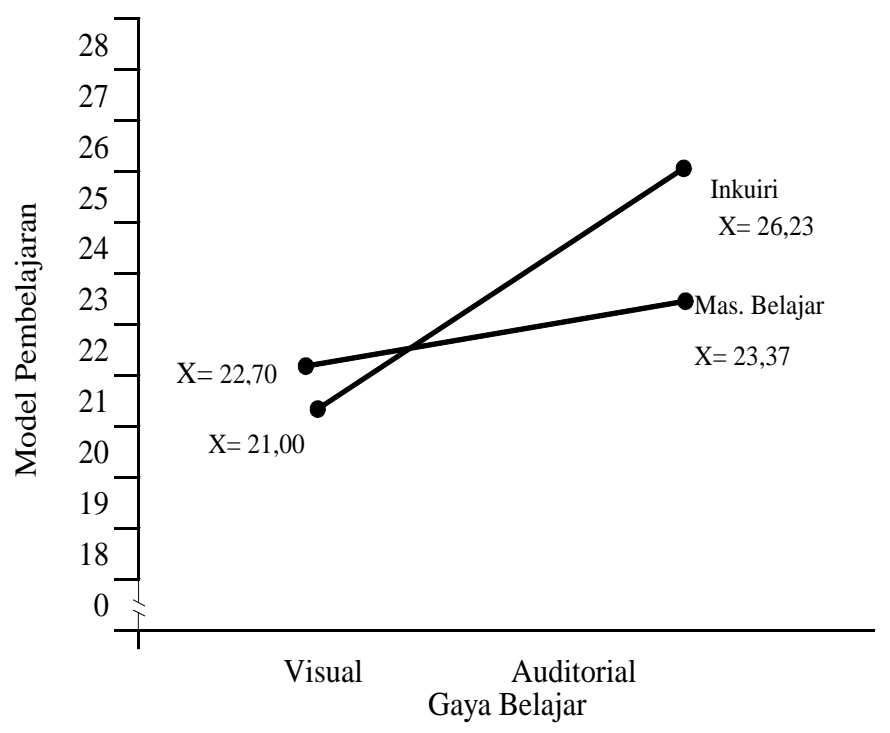

Gambar 1. Interaksi Model Pembelajaran dan Gaya Belajar terhadap Hasil Belajar Matematika.

Berdasarkan hasil pengujian hipotesis ketiga yang menyatakan adanya interaksi antara model pembelajaran dengan gaya belajar, maka perlu dilakukan uji perbedaan rata-rata antara dua proporsi. Gambar 1. menunjukkan pengaruh dan interaksi dari model pembelajaran dan gaya belajar terhadap hasil belajar matematika yang diperoleh siswa, rata-rata hasil belajar matematika siswa yang diajar dengan model inkuiri lebih tinggi dibandingkan dengan model pembelajaran masyarakat belajar. Penelitian ini juga membuktikan faktor gaya belajar sebagai salah satu karakteristik siswa perlu pula diperhatikan karena terbukti bahwa gaya belajar berpengaruh terhadap hasil belajar matematika. 


\section{Pembahasan Hasil Penelitian}

Dari hasil pengolahan data yang dilakukan terdapat perbedaan hasil belajar matematika antara siswa kelas VI SD Negeri 118299 Aek Raso yang diajar dengan model inkuiri dengan model pembelajaran masyarakat belajar, yaitu rata-rata hasil belajar matematika siswa yang diajar dengan model inkuiri lebih tinggi daripada rata-rata hasil belajar matematika siswa yang diajar dengan model pembelajaran masyarakat belajar. Kenyataan ini membuktikan bahwa model inkuiri lebih baik dalam meningkatkan pemahaman siswa dalam pembelajaran matematika daripada penggunaan model pembelajaran masyarakat belajar. Dengan demikian mengajarkan materi ajar matematika untuk beberapa kompetensi dasar seperti menggunakan teorema sissa dan teorema factor dalam pemecahan masalah akan lebih baik menggunakan model inkuiri dibanding dengan model pembelajaran masyarakat belajar, karena dalam kompetensi dasar ini siswa diharuskan memiliki kemampuan pemecahan masalah yang dapat dilakukan dengan proses penemuan.

Namun demikian berdasarkan hasil penelitian dapat diketahui bahwa model pembelajaran inkuiri maupun masyarakat belajar menempatkan siswa sebagai subjek belajar, bukan hanya sebagai pendengar, tetapi mereka berperan untuk menemukan sendiri inti dari materi pelajaran itu sendiri, selain itu aktivitas ini juga diharapkan dapat diharapkan dapat menumbuhkan sikap percaya diri (selfbelief) pada diri siswa. Hal ini sesuai pula dengan teori yang dikemukakan oleh Joyce dan Weil (2009) bahwa belajar dengan cara menemukan sendiri dapat dipercaya dalam mengembangkan kemandirian, anak-anak mempunyai rasa ingin tahu untuk tumbuh, belajar dengan menemukan merupakan bekal dalam menggali semangat anak, memberikan bimbingan secara khusus sehingga mereka dapat memahami suatu gagasan yang lebih luas.

Hasil penemuan ini juga sesuai dengan teori yang dikemukakan olah Bruner dalam Hasibuan dan Moejiono (1993) yang mengemukakan bahwa pencarian (inkuiri) mengandung makna sebagai berikut: (1) dapat membangkitkan potensi intelektual siswa karena seseorang hanya dapat belajar dan mengembangkan pikirannya jika ia menggunakan potensi inlelektualnya untuk berpikir; (2) siswa yang semula memperoleh extrinsic reward dalam keberhasilan belajar (mendapat nilai yang baik), dalam pendekatan inkuiri akan dapat memperoleh intrinsic reward (kepuasan diri), (3) siswa dapat mempelajari heuristik (mengolah pesan atau informasi) dari penemuan, artinya bahwa cara untuk mempelajari teknik penemuan ialah dengan jalan memberikan kesempatan kepada siswa untuk mengadakan penelitian sendiri, dan (4) dapat menyebabkan ingatan bertahan lama sampai internalisasi pada diri siswa.

Hasil penelitian ini juga mendukung penelitian sebelumnya yang dilakukan oleh Darajat (2004) mendapatkan kesimpulan bahwa metode pembelajaran discoveri dengan bimbingan lebih efektif digunakan dari pada metode masyarakat belajar dalam meningkatkan hasil belajar fisika siswa. Hasil penelitian yang dilakukan oleh Dewi (1999) mengemukakan bahwa keberhasilan menemukan sendiri dapat menimbulkan rasa puas dan gembira pada diri siswa yang akhirnya menimbulkan rasa ingin belajar sendiri dan menimbulkan daya kreativitas siswa. Hasil penelitian ini juga sesuai dengan temuan Mukhadis (2003) dalam penelitiannya yang menunjukkan pengaruh latihan inkuiri terhadap prestasi belajar tipe prosedural, di mana hasil penelitiannya menemukan bahwa kelebihan latihan inkuiri dalam meningkatkan hasil dan transfer belajar, yakni pengenalan pola, urutan tindakan dan gabungan keduanya disebabkan adanya penerapan empat macam komponen model yaitu urutan latihan inkuiri, urutan prasyarat belajar, rangkuman dan sintesis yang secara sistematis tidak terdapat dalam model urutan linier bertahap. Keempat macam komponen model ini memiliki potensi untuk memudahkan proses penstrukturan pengalaman belajar isi prosedural dalam proses pembentukan struktur kognitif baru.

Hasil penelitian menunjukkan bahwa rata-rata hasil belajar Matematika siswa yang memiliki gaya belajar visual lebih tinggi daripada hasil belajar matematika siswa yang memiliki gaya belajar auditorial. Selanjutnya dalam penelitian ini juga terbukti bahwa hasil belajar matematika siswa yang memiliki gaya belajar visual yang diajar dengan Model pembelajaran inkuiri lebih tinggi daripada hasil belajar matematika siswa yang diajar dengan Model pembelajaran masyarakat belajar. Hal ini mengindikasikan bahwa siswa yang mempunyai gaya belajar visual lebih mampu memahami bahan pelajaran matematika dibandingkan siswa yang mempunyai gaya belajar auditorial. 
Penelitian ini juga membuktikan bahwa siswa yang memiliki gaya belajar visual lebih cocok diajar dengan menggunakan Model inkuiri. Pembelajaran dengan Model inkuiri sangat tepat dibandingkan model pembelajaran masyarakat belajar untuk diterapkan pada siswa yang memiliki gaya belajar visual.

Berdasarkan skor hasil penelitian beberapa siswa dalam kelompok visual memperolah skor di bawah rata-rata, hal ini disebabkan oleh beberapa hal, dia antaranya suasana kelas dengan jumlah siswa yang cukup besar dan kegiatan pembelajaran yang memungkinkan siswa banyak mengeluarkan suara menjadi kendala pada siswa kelompok visual yang merasa sulit belajar dalam suasana yang tidak tenang dan banyak gangguan, siswa kelompok ini juga merasa sulit memahami penjelasan guru tanpa disertai dengan gambar atau bagan, dan terganggu konsentrasinya saat melihat tampilan (baik penampilan seseorang atau tampilan suatu informasi) yang menurutnya tidak menarik atau justru jelek hal ini tampak sekali terjadi pada model pembelajaran masyarakat belajar, berbagai penampilan siswa dalam mengemukakan pendapat mempengaruhi persepsi siswa terhadap materi pelajaran yang disajikan

Penelitian ini juga mendukung teori yang dikemukakan dikemukakan oleh dePorter dan hernacki (1992) bahwa ciri-ciri tersebut antara lain: (1) Orang -orang Visual mempunyai ciriciri, rapi dan teratur; berbicara dengan cepat; perencana dan pengatur jangka panjang yang baik; teliti terhadap detail; mementingkan penampilan, baik dalam hal pakaian maupun presentasi;pengeja yang baik dan dapat melihat kata-kata yang sebenarnya dalam pikiran mereka; mengingat apa yang dilihat, daripada yang didengar; mengingat dengan assosiasi visual; biasanya tidak terganggu oleh keributan; mempunyai masalah untuk mengingat instruksi verbal kecuali jika ditulis, dan seringkali minta bantuan orang untuk mengulanginya; pembaca cepat dan tekun; lebih suka membaca daripada dibacakan; membutuhkan pandangan dan tujuan yang menyeluruh dan bersikap waspada sebelum mental merasa pasti tentang suatu masalah atau proyek; mencoret-coret tanpa arti selama berbicara di telepon dan dalam rapat;lupa menyampaikan pesan verbal kepada orang lain; sering menjawab pertanyaan dengan jawaban singkat ya atau tidak; lebih suka melakukan demonstrasi daripada berpidato; lebih suka seni daripada musik
Hasil penelitian ini juga mendukung penelitian sebelumnya yang dilaporkan oleh Sinaga (2007) yang menyatakan hasil belajar mahasiswa yang memiliki gaya belajar visual, auditorial dan kinestetik berbeda secara signifikan, yaitu hasil belajar kebutuhan dasar manusia I mahasiswa Akper Langkat untuk mahasiswa yang memiliki gaya belajar kinestetik lebih tinggi dibandingkan hasil belajar mahasiswa yang memiliki gaya belajar visual dan auditorial.

Temuan penelitian menunjukkan bahwa terdapat interaksi antara Model pembelajaran dan gaya belajar terhadap hasil belajar matematika siswa kelas VI SD Negeri 118299 Aek Raso. Siswa yang memiliki gaya belajar visual yang diajar dengan model inkuiri lebih tinggi hasil belajar matematikanya daripada siswa yang memiliki gaya belajar auditorial yang diajar dengan model inkuiri. Demikian pula siswa yang memiliki gaya belajar auditorialyang diajar dengan model pembelajaran masyarakat belajar memperoleh hasil belajar matematika yang lebih tinggi daripada siswa yang memiliki gaya belajar visual dengan Model pembelajaran masyarakat belajar. Hal ini mengindikasikan adanya interaksi antara model pembelajaran dengan gaya belajar terhadap hasil belajar matematika siswa.

Siswa yang memiliki gaya belajar auditorial jika diajar dengan model pembelajaran inkuiri akan mengalami kesulitan untuk membangun atau mengkonstruk pengetahuan dan keterampilan matematika yang dibutuhkannya, sebab siswa dengan gaya belajar auditorial memiliki tingkat kecepatan yang rendah dalam menyelesaikan soal-soal matematika. Pembelajaran inkuiri menuntut kemampuan dalam menyelesaikan soal-soal secara rinci, terurut, dan sistematis. Sebaliknya siswa yang memiliki gaya belajar auditorial akan mudah belajar dengan menggunakan model pembelajaran masyarakat belajar, karena model ini mengarahkan siswa pada sejumlah informasi yang membawa mereka memhami situasi sosial yang ada disekelilingnya.

Hal tersebut tidak mampu dilakukan oleh siswa dengan gaya belajar auditorial, sebab struktur kognitif siswa dengan gaya belajar auditorial, belajar dengan mendengarkan dan mengingat apa yang didiskusikan daripada yang dilihat, artinya siswa dengan gaya belajar auditorial membutuhkan waktu dan proses pembelajaran yang lebih lama untuk mencerna 
suatu materi pelajaran matematika yang baru, sebab lebih mengedepankan komunikasi verbal, cenderung mengingat dengan baik dan menghafal kata-kata dan gagasan-gagasan yang pernah diucapkan.

Hasil penelitian ini mendukung penelitian sebelumnya yang dikemukakan oleh Sutrisno (2006) yang mengemukakan bahwa siswa yang memiliki gaya belajar visual jika dibelajarkan dengan model latihan inkuiri memperoleh hasil belajar kimia yang lebih tinggi dibandingkan dengan jika dibelajarkan dengan model konvensional. Sebaliknya, siswa yang memiliki gaya belajar auditorial jika dibelajarkan dengan model konvensional memperoleh hasil belajar matematika yang lebih tinggi dibandingkan dengan jika dibelajarkan dengan model latihan inkuiri.

\section{PENUTUP}

Berdasarkan hasil penelitian dan pembahasan yang dikemukakan sebelumnya, maka dapat simpulakan bawah :

1. Hasil belajar matematika siswa yang diajarkan dengan model inkuiri lebih tinggi dibandingkan dengan hasil belajar matematika siswa yang diajarkan dengan model pembelajaran masyarakat belajar di SD Negeri 118299 Aek Raso.

2. Hasil belajar matematika siswa yang memiliki gaya belajar visual lebih tinggi daripada siswa yang memiliki gaya belajar auditorial di SD Negeri 118299 Aek Raso.

3. Terdapat interaksi antara model pembelajaran dan gaya belajar yang memberikan perbedaan pengaruh terhadap hasil belajar matematika siswa. Perbedaan pengaruh tersebut adalah: (1) Hasil belajar matematika siswa dengan gaya belajar visual yang diajar dengan model inkuiri lebih tinggi daripada hasil belajar siswa dengan model pembelajaran masyarakat belajar; (2) Hasil belajar matematika siswa dengan gaya belajar visual yang diajar dengan model inkuiri lebih tinggi daripada hasil belajar siswa dengan gaya belajar auditorial yang diajar dengan model pembelajaran inkuiri; (3) Hasil belajar matematika siswa dengan gaya belajar visual yang diajar dengan pembelajaran inkuiri lebih tinggi dari hasil belajar siswa dengan gaya belajar auditorial yang diajar dengan model pembelajaran masyarakat belajar; (4) Hasil belajar matematika siswa dengan gaya belajar auditorial yang diajar dengan model inkuiri lebih tinggi daripada hasil belajar siswa dengan gaya belajar auditorial yang diajar dengan model pembelajaran masyarakat belajar; (5) Hasil belajar matematika siswa dengan gaya relajar visual yang diajar dengan model masyarakat belajar lebih tinggi daripada hasil belajar siswa dengan gaya relajar auditorial yang diajar dengan model pembelajaran masyarakat belajar; (6) Hasil belajar matematika siswa dengan gaya belajar auditorial yang diajar dengan model pembelajaran masyarakat belajar lebih tinggi daripada hasil belajar siswa dengan gaya belajar auditorial yang diajar dengan model pembelajaran inkuiri.

\section{DAFTAR PUSTAKA}

Amin, Moh. (1987). Mengajarkan Ilmu Pengetahuan Alam dengan Menggunakan Metode "Discovery" dan "Inquiry". Jakarta: Depdikbud-Dirjen Dikti.

Dahar, Ratna Wilis, (1989), Teori Belajar, Jakarta : Erlangga Press

Daradjat, Zakiah. (20050. Pendidikan Islam Dalam Keluarga Dan Sekolah. Jakarta : Ruhama.

Departemen Pendidikan Nasional, (2006), Standar Kompetensi Lulusan untuk Satuan Pendidikan Dasar dan Menengah, Jakarta: Direktorat Jendral Manajemen Pendidikan Dasar dan Menengah Kementerian Pendidikan Nasional.

Departemen Pendidikan Nasional. (2003). Undang-Undang Nomor 20 Tahun 2003. Tentang Sistem Pendidikan Nasional. Jakarta: Depdiknas.

DePorter, Bobbi dan Mike Hernacki. (1992). Quantum Learning: Unleasing The Genius In You. New York: Dell Publishing. Terjemahan: Alwiyah Abdurrahman. h. 310.

Dryden, Gorden dan Jeanette Vos. (2003). The Learning Revoluton. Bandung : Kaifa.

Fudyartanta. (2002). Psikologi Pendidikan dengan Pendekatan Baru. Yogyakarta: Global Pustaka Utama

Gunawan, Adi. (2004). Genius Learning Strategy petunjuk Praktis untuk Menerapkan Accelerated Learning. Jakarta: PT Gramedia Pustaka Utama

Hadi, Sutrisno. (2006). Metodologi Research. Yogyakarta: Pustaka Pelajar 
Hasibuan, JJ. dan Mujiono. (1993). Proses Belajar Mengajar. Bandung: PT. Remaja Rosdakarya.

Ibnu, Mukhadis, Dasna, (2003). Dasar-dasar Metodologi Penelitian. Malang: Universitas Negeri Malang.

Joyce, B \& Weil. (2009). Model-model Pengajaran. Edisi 8. Terjemahan A. Fuwaid \& A. Mirza. Yogyakarta: Pustaka Pelajar.

Madden, Thomas L. (2002). Fire-Up. Jakarta : Gramedia Pustaka Utama.

McMillan, D.W., \& Chavis, D.M. (1986). Sense of community: A definition and theory. American Journal of Community Psychology, 14 (1), 6-23.

Nurhadi. 2004. Kurikulum 2004 (Pertanyaan dan Jawaban). Jakarta; PT. Grasindo

Sinaga, Bornok. (2007). Pengembangan Model Pembelajaran Matematika Berdasarkan Masalah Berbasis Budaya Batak (PBMB3). Disertasi. Surabaya: Program
Pascasarjana Universitas Negeri Surabaya.

Sudjana, Nana. (2008). Penilaian Hasil Proses Belajar Mengajar. Bandung: PT. Remaja Rosdakarya.

Sutrisno. (2012). Efektivitas Pembelajaran dengan Metode Penemuan Terbimbing terhadap Pemahaman Konsep Matematis Siswa. Jurnal Pendidikan Matematika. 1 (4)

Tirtarahardja, Umar \& La Sulo. (2005). Pengantar Pendidikan. PT Rineka Cipta.

Trianto. (2007). Model-model Pembelajaran Inovatif Berorientasi Konstruktivistik: Konsep, landasan Teoritis-Praktis dan Implementasinya. Jakarta: Prestasi Pustaka Publisher.

Wardani. (2005). Pembelajaran dan Penilaian hasil Belajar Matematika SMP Aspek Pemahaman Konsep, Penalaran dan Komunikasi, Pemecahan Masalah. Yogyakarta: PPPGN Matematika. 